Reprod. Nutr. Dévelop., 1987, 27 (1 A), 57-66.

\title{
Valorization of rapeseed meal. 3. Effects of glucosinolate content on food intake, weight gain, liver weight and plasma thyroid hormone levels in growing rats
}

\author{
M. VERMOREL, Marie-Jeanne DAVICCO $\left({ }^{*}\right)$, J. EVRARD $\left.{ }^{* *}\right)$ \\ with the technical assistance of $Y$. ANGLARET, M. GENEST, C. LEOTY, Marinett MEYER \\ et R. SOUCHET \\ Laboratoire d'Etude du Métabolisme Energétique, \\ (*) Laboratoire des Maladies Métaboliques, \\ I.N.R.A., Theix 63122 Ceyrat, France. \\ (*) CETIOM, Centre Technique Interprofessionnel des Oléagineux Métropolitains, \\ rue Monge, Parc Industriel, 33600 Pessac, France.
}

Summary. Seven groups of 10 growing rats each were fed a control diet or rapeseed diets with glucosinolate contents ranging from 4.4 to $36.6 \mathrm{mM} / \mathrm{kg} \mathrm{DM}$. After a 5-day adaptation period, the rats were fed ad libitum for 17 days.

The food intake of the experimental groups was maximal after 11 days and was, on an average, 4 to $45 \%$ lower than that of the control group. The differences were still greater during the last 7 days. Daily weight gain was also maximal after 8 days and began to decrease, dropping to $1 \mathrm{~g}$ during the last days. There were negative curvilinear relationships between food intake or weight gain and diet glucosinolate content.

Liver weight $(\mathrm{g} / 100 \mathrm{~g}$ of body weight) was not significantly altered by glucosinolate intakes between 0.08 and $0.39 \mathrm{mM} /$ day. However, in the groups fed the diets with the lowest glucosinolate contents, plasma triiodothyronine $\left(T_{3}\right)$ and thyroxine $\left(T_{4}\right)$ levels were $50 \%$ lower than in the control group and 70 or $80 \%$ lower, respectively, with the diets having the highest glucosinolate contents.

\section{Introduction.}

The meals obtained from the first new rapeseed cultivars bred in France (Morice, 1974) or in other countries (Tower, Line and Erglu) had very low glucosinolate contents (8 to $15 \mathrm{mM} / \mathrm{kg}$ of dry matter, DM) which permitted their use at high concentrations in animal feeds (McKinnon and Bowland, 1977 ; Vermorel, Fayet and Baudet, 1978 ; review by Rundgren, 1983 ; Thomke et al., 1983 ; Bell, 1984). However, their agronomic yield was low. In France, crosses of the original lines with highly productive varieties made it possible to breed new varieties, such as Tandem and Darmor, which have yields very similar to those of the older types of rapeseed high in glucosinolates (Morice, 1983). However, the increase in yield was accompanied by a relative increase in glucosinolate content significantly higher than that of the first varieties cited but 3 to 5 times lower than 
that of older varieties. Moreover, these contents varied from 30 to $60 \mathrm{mM} / \mathrm{g} \mathrm{DM}$ according to region and growing conditions (results of CETIOM trials).

Many studies have shown that low-glucosinolate rapeseed meal is a useful source of protein, but not much systematic work has been done on the effects of the glucosinolate content of diets on animal performance and its physiological and pathological consequences. Only Narendran et al. (1981) and Thomke (1984) reported feeding trials on growing pigs with very low glucosinolate meals from Tower and Karat rapeseed varieties containing 5 and $11 \mathrm{mM}$ of total glucosinolates $/ \mathrm{kg}$, respectively. Thus, it appeared necessary to determine the conditions for maximal utilization of French rapeseeds in the diets of growing pigs according to their glucosinolate content. Growing rats were used as experimental models to determine whether the effects observed were directly proportional to glucosinolate intakes.

\section{Material and methods.}

Feeds and diets. - Seven balanced diets with increasing glucosinolate contents were constituted using, in various proportions as protein sources, rapeseed meal from the Jet Neuf and Tandem varieties (both dehulled) and herring meal. The Jet Neuf rape seeds had been almost completely dehulled using CETIOM experimental equipment, followed by a mild heat treatment with no cooking or pressure, hexane extraction and desolventization at $60^{\circ} \mathrm{C}$. The seeds of Tandem were dehulled and treated according to the method of Choné (1983) : cooking and pressure at $70^{\circ} \mathrm{C}$, then at $90^{\circ} \mathrm{C}$, extraction with hexane and desolventization at $65{ }^{\circ} \mathrm{C}$. The total glucosinolate (GI), isothiocyanate (ITC) and vinyloxazolidene-2thione (VTO) contents of the rapeseed meals were determined by the methods of Thies (1978) and Youngs and Wetter (1967), respectively.

The total glucosinolate content of the Jet Neuf sample used was particularly high, whereas that of Tandem was much lower (33 vs $210 \mathrm{mM} / \mathrm{kg} \mathrm{DM}$ ) (table 1). Thus, it was possible to obtain a wide range of glucosinolate concentrations in diets with similar proportions of rapeseed meal $(21$ to $26 \%)$. The proportions of VTO in the total glucosinolates were comparable in the two meals, but those of ITC were relatively (23\%) lower in Tandem meal. The protein contents of the two meals were high, being $10 \%$ more with Tandem due to a lower cell-wall car-

\section{TABLE 1}

Composition of the 2 samples of rapeseed meal used.

\begin{tabular}{ccccccccc}
\hline $\begin{array}{c}\text { Rapeseed } \\
\text { meal }\end{array}$ & $\begin{array}{c}\mathrm{DM} \\
(\%)\end{array}$ & $\begin{array}{c}\mathrm{N} \times 6.25 \\
(\% \mathrm{DM})\end{array}$ & $\begin{array}{c}\text { Avail } \\
\text { lysine } \\
(\% \mathrm{DM})\end{array}$ & $\begin{array}{c}\text { Crude } \\
\text { fiber } \\
(\% \mathrm{DM})\end{array}$ & $\begin{array}{c}\text { Fat } \\
(\% \mathrm{MS})\end{array}$ & $\begin{array}{c}\text { Glucosi- } \\
\text { nolates } \\
\mathrm{mM} / \mathrm{kg} \\
\mathrm{DM}\end{array}$ & $\begin{array}{c}\text { ITC } \\
\mathrm{mM} / \mathrm{kg} \\
\mathrm{DM}\end{array}$ & $\begin{array}{c}\mathrm{VM} / \mathrm{kg} \\
\mathrm{mM}\end{array}$ \\
\hline $\begin{array}{c}\text { Jet Neuf } \\
\text { Tandem }\end{array}$ & 92.45 & 46.02 & 2.17 & 4.9 & 2.65 & 210 & 68 & 151 \\
\hline
\end{tabular}


bohydrate content (17.8 vs $34.3 \%$ of NDF). In reverse, the available lysine content (acid orange 12 method) was lower for Tandem meal than for Jet Neuf $(4.5$ vs $4.72 \%$ of protein).

In control diet 1, methionine-supplemented herring meal was the sole protein source. In diet 2, half, and in diet 3, all, the protein was provided by meal from Tandem rapeseed. In diets 4 to $7,20 \%$ of the proteins came from herring meal and $80 \%$ from varying proportions of Tandem and Jet Neuf meals in order to obtain a range of dietary glucosinolate contents increasing from 0 to $36.6 \mathrm{mM} / \mathrm{kg}$ OM (table 2).

TABLE 2

Percentages of proteins provided from the 3 sources and glucosinolate content of the different diets.

\begin{tabular}{|c|c|c|c|c|c|c|}
\hline \multirow{3}{*}{ Diets } & \multicolumn{3}{|c|}{$\%$ of dietary protein } & \multicolumn{3}{|c|}{ Glucosinolate contents } \\
\hline & \multirow{2}{*}{$\begin{array}{l}\text { Herring } \\
\text { Meal }\end{array}$} & \multicolumn{2}{|c|}{ Rapeseed meal } & \multirow{2}{*}{$\stackrel{\mathrm{ITC}}{\mathrm{mM} / \mathrm{kg} \mathrm{DM}}$} & \multirow{2}{*}{$\begin{array}{c}\text { VTO } \\
\mathrm{mM} / \mathrm{kg} \text { DM }\end{array}$} & \multirow{2}{*}{$\begin{array}{c}\text { Total } \\
\mathrm{mM} / \mathrm{kg} \mathrm{DM}\end{array}$} \\
\hline & & $\begin{array}{l}\text { Dehulled } \\
\text { Jet Neuf }\end{array}$ & $\begin{array}{l}\text { Dehulled } \\
\text { Tandem }\end{array}$ & & & \\
\hline 1 & 100 & 0 & 0 & 0 & 0 & 0 \\
\hline 2 & 50 & 0 & 50 & 1.1 & 3.1 & 4.4 \\
\hline 3 & 0 & 0 & 100 & 2.2 & 6.2 & 8.8 \\
\hline 4 & 20 & 12 & 68 & 3.8 & 9.3 & 13.4 \\
\hline 5 & 20 & 24 & 56 & 5.5 & 12.8 & 18.3 \\
\hline 6 & 20 & 40 & 40 & 8.7 & 19.8 & 28.2 \\
\hline 7 & 20 & 56 & 24 & 11.5 & 25.7 & 36.6 \\
\hline
\end{tabular}

Diet composition is given in table 3. All the diets were supplemented with lysine and/or methionine to meet the essential amino acid requirements of growing rats (Vermorel, 1972), taking into account the estimated protein digestibility of the diets.

TABLE 3

Diet composition (g DM/kg DM).

\begin{tabular}{lccccccc}
\hline \multicolumn{1}{c}{ Diet No } & 1 & 2 & 3 & 4 & 5 & 6 & 7 \\
\hline Herring meal & 150 & 75 & 0 & 32 & 32 & 32 & 32 \\
RSM $^{*}$ Tandem & 0 & 133 & 265 & 177.7 & 146 & 104.6 & 62.6 \\
RSM Jet Neuf & 0 & 0 & 0 & 34.8 & 62.6 & 115 & 160.6 \\
L-Lysine-HCl & 0 & 0.30 & 0.60 & 0.60 & 0.60 & 0.60 & 0.60 \\
DL-Methionine & 2.5 & 1.25 & 0 & 0 & 0 & 0 & 0 \\
Maize starch & 769.5 & 713 & 656.4 & 708.9 & 680.8 & 669.8 & 698.2 \\
\hline Crude protein content & 124 & 131 & 137 & 129 & 131 & 135 & 130 \\
\hline
\end{tabular}

All diets also contained per $\mathrm{kg}$ DM : $40 \mathrm{~g}$ mineral mixture, $18 \mathrm{~g}$ vitamin mixture, $20 \mathrm{~g}$ vitamined maïze oil (A.D.E.) biotin and choline.

* RSM : rapeseed meal. 
Animals. - Seventy male Sprague-Dawley rats of average weight $(75 \mathrm{~g})$ were randomly allotted to 7 groups of 10 animals each. Each group received one of the 7 diets described during a period of 22 days.

Feeding. - The diets were fed in the form of wet mash to avoid wastage. To adapt the rats easily to the experimental diets, the diets were fed mixed with the control diet in increasing proportions $(1 / 4,1 / 2,3 / 4)$ during the first 3 days, then alone and ad libitum for 19 days.

Measurements. - The individual quantities of dry feed distributed, refused and ingested by the rats were determined each day. The rats were weighed at a set time twice a week and on the last day.

At the end of the experiments, 5 rats from each group were anaesthetized with ether and $2 \mathrm{ml}$ of blood were collected by cardiac puncture for determination of thyroid hormone concentrations. The other rats were asphyxiated with ether. The liver and gut contents were removed from all the animals; the latter were used to determine empty body weight gain (EBWG). Plasma triiodothyronine $\left(T_{3}\right)$ and thyroxine $\left(T_{4}\right)$ contents were determined by radioimmunoassay (RIA Kit T3 and RIA Kit T4, Amersham). The results were tested by analysis of variance and Student's t-test or the U-test of Mann-Whitney in the case of thyroid hormones (5 rats per group) (Snedecor and Cochran, 1968).

\section{Results.}

Feed intake. - Feed intake increased regularly in groups 1 (control) and 2 (4.4 $\mathrm{mM} \mathrm{GI} / \mathrm{kg} \mathrm{DM}$ ), in spite of an unexplained reduction between days 8 and 11 .
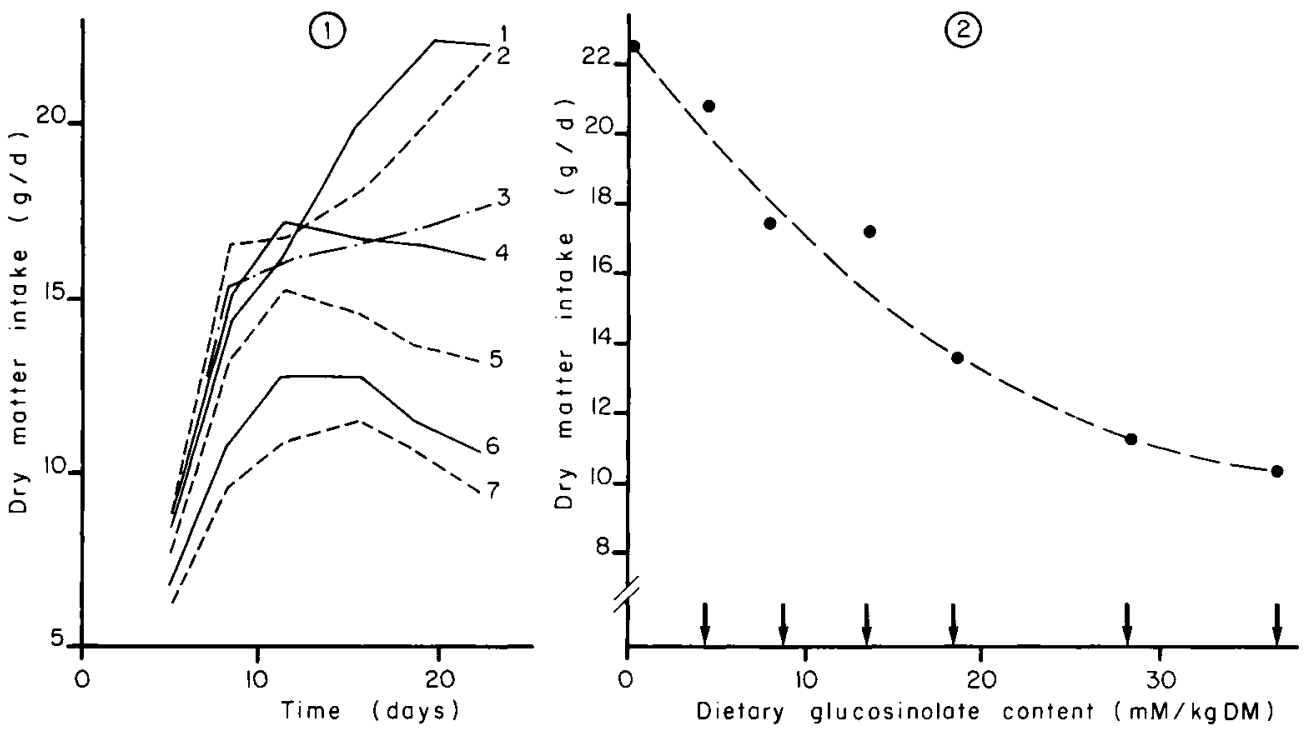

FIG. 1. - Variation in dry matter intake during the trial.

FIG. 2. - Variation in dry matter intake between days 16 and 22 of the experiment (Ordinate : dry matter intake ( $\mathrm{g} / \mathrm{d})$; absciss : dietary g/ucosinolate content) (mM/kg DM). 
The increased intake of rats of group $3(8.8 \mathrm{mM}$ Gl) slowed down after day 8 . This phenomenon was even more accentuated with diets 4 to 7 , where intake stopped increasing or decreased after day 8 or 15 (fig. 1).

During the period the pure diets were fed ad libitum, the average intakes of the rats in groups 2,3 and 4 were 4,15 and $15 \%$ lower, respectively, than those in the control group $(P<0.01)$. The differences were even greater $(27,39$ and $45 \%$ ) for groups 5,6 and 7 , respectively $(P<0.001$ ) (table 4 ). These differences also increased during the last 7 days of the trial, reaching 39,50 and $54 \%$ for groups 5,6 and 7 , respectively (fig. 2 ).

Body weight gain. - After adaptation, the live weight gain of rats in group 1 (control) and group $2(4.4 \mathrm{mM} \mathrm{Gl})$ was rather constant. The growth rate of rats in groups 3 to 7 decreased as the dietary glucosinolate concentration increased. The growth curves dropped markedly from about day 11 (fig. 3) due to the stabilization and then reduction in daily weight gain which became noticeable between days 8 and 11 and accelerated from day 15 (fig. 4). During the last days of experimentation, the live weight gain of rats in groups 6 and $7(28.2$ and $36.6 \mathrm{mM} \mathrm{Gl})$ was reduced to about $1 \mathrm{~g} /$ day.
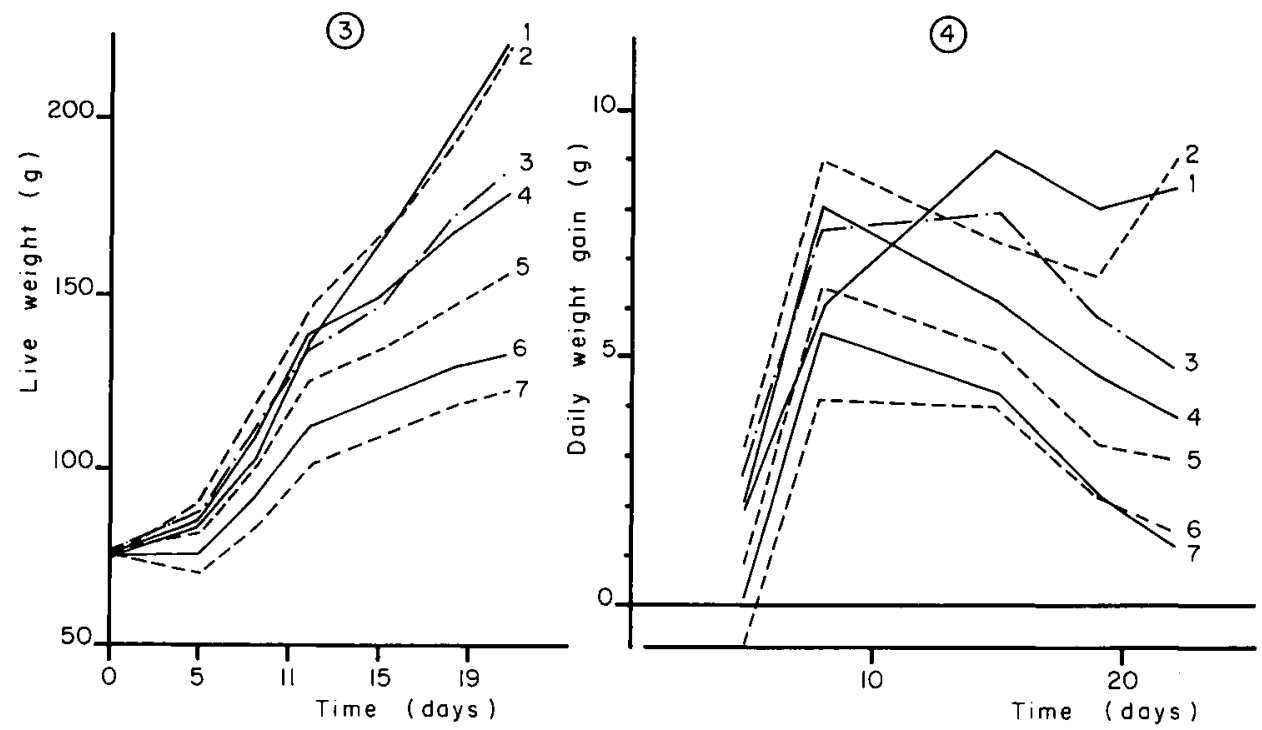

FIG. 3. - Variation in rat live weight during the trial.

FIG. 4. - Variation in rat weight gain ( $\mathrm{g} /$ day) during the trial.

There was a close curvilinear relationship between daily weight gain and dietary glucosinolate content which varied between 8.1 and $3.0 \mathrm{~g} /$ day for the first 17 days (table 4) and between 8.3 and $1.8 \mathrm{~g} /$ day during the last 7 days (fig. 5 ). The difference in weight gain between groups 6 and 7 was not significant either during the first 17 days or the last 7 days, in spite of a $30 \%$ higher glucosinolate 


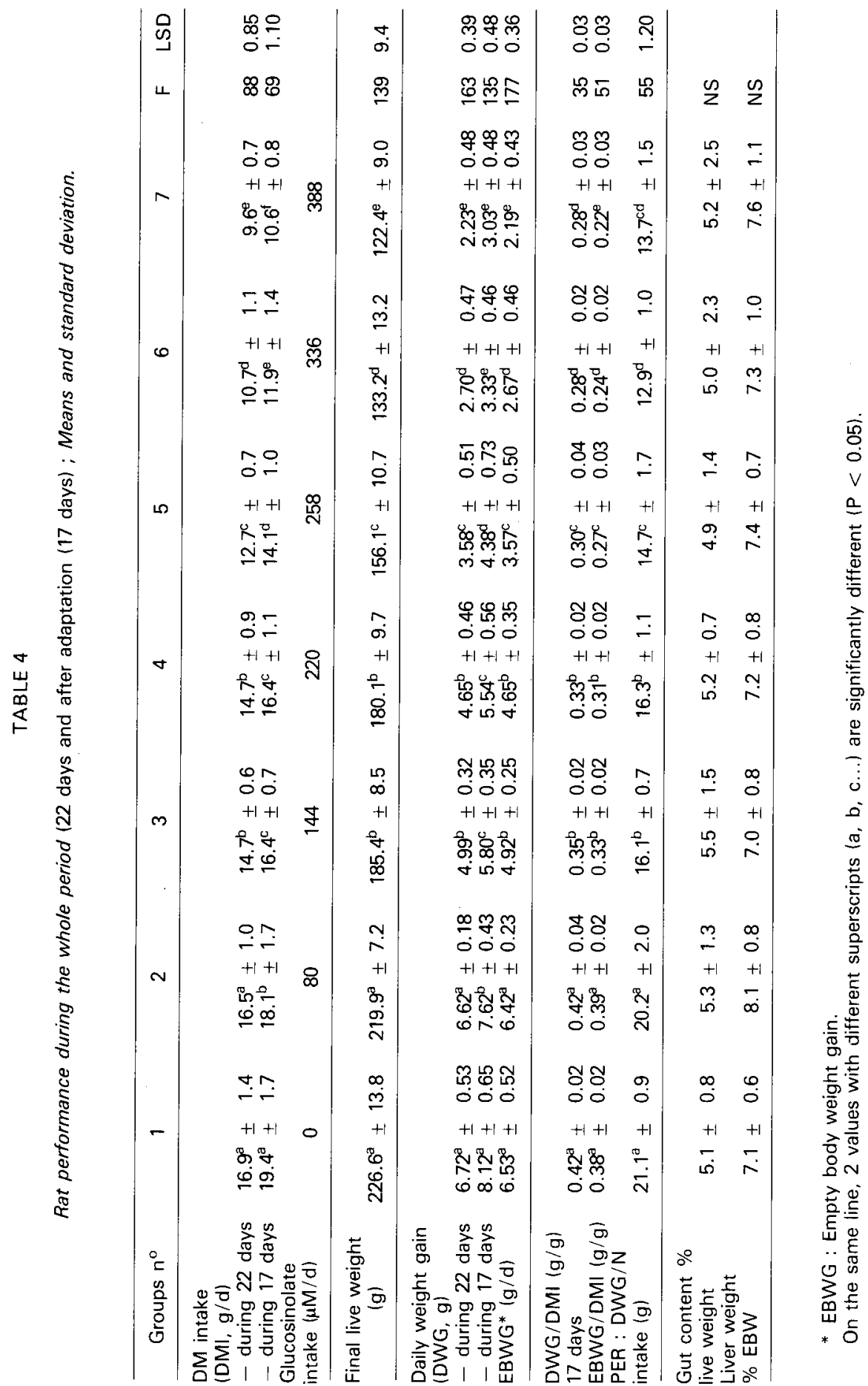


content in diet 7 ; but animal performance was poor, especially during the last days.

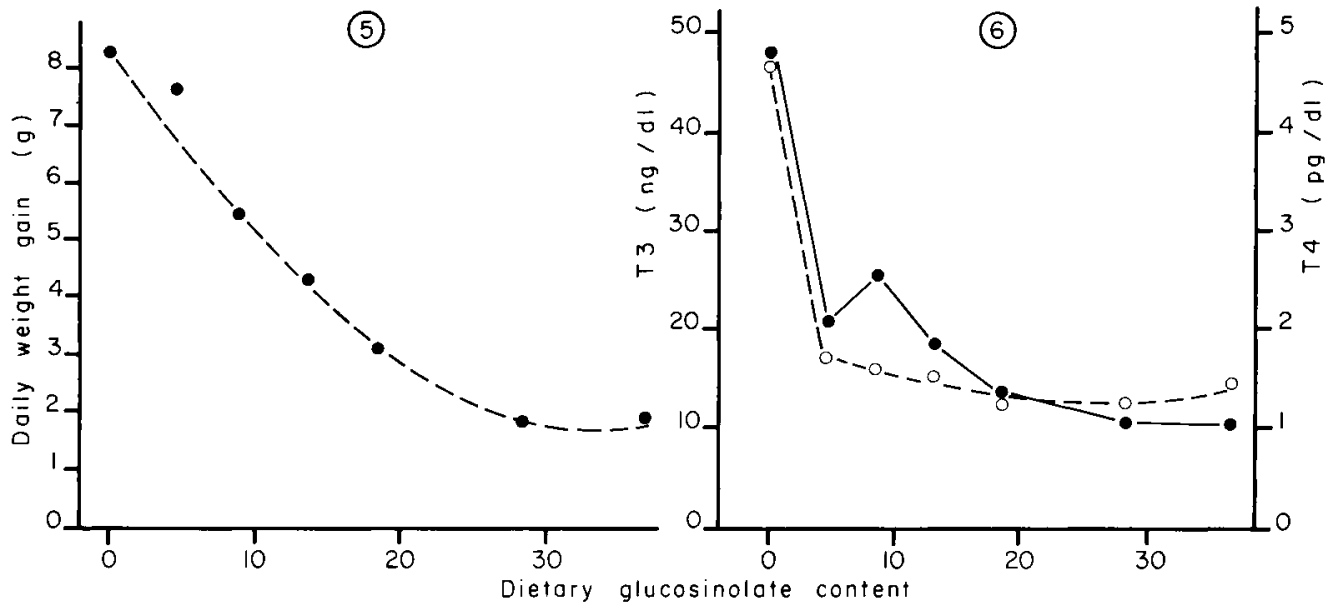

FIG. 5. - Variation in rat live weight gain between days 15 and 22 of trial, in relation to g/ucosinolate content of the diet $(\mathrm{mM} / \mathrm{kg} \mathrm{DM})$.

FIG. 6. - Variation in trijodothyroinine $\left(\mathrm{T}^{3}\right)(0)$ and thyroxine $\left(\mathrm{T}^{4}\right)(0)$ in plasma of rats after 22 days of experimentation, in relation to dietary g/ucosinolate content $(\mathrm{mM} / \mathrm{kg} \mathrm{DM})$.

Feed efficiency. - During the period when the diets were fed pure and ad libitum, there was no significant difference between groups 1 and 2 . In contrast, feed efficiency was reduced by $16,20,27,34$ and $33 \%$ for diets 3, 4, 5, 6 and 7 , respectively $(P<0.001$ ) (table 4$)$. Similarly, the protein efficiency ratio (live weight gain $/ \mathrm{N}$ intake) was not significantly different between groups 1 and 2, but was 24, 23, 30, 39 and $35 \%$ lower for groups 3, 4, 5, 6 and 7, respectively $(P<0.001)$. These differences were probably due to the reduced protein digestibility of diets rich in rapeseed meal and to the reduction in growth rate.

Liver weight. - Rat liver weight increased with total body weight, generally representing about $7.4 \%$ of live weight (table 4 ). There were no differences among the 7 groups, in spite of the different glucosinolate contents of diets and intake $(0$ to $388 \mathrm{mM}$ /day on an average). Furthermore, no macroscopic anomaly was observed.

Plasma concentrations of thyroid hormones. - After the 22-day period, $T_{3}$ and $T_{4}$ levels in plasma from rats fed the rapeseed diets were all significantly lower than those of the controls $(P<0.01$ ) (table 5 ). For groups 2 and 3 (4.4 and $8.8 \mathrm{mM} \mathrm{GI}$ ), the plasma $T_{4}$ and $T_{3}$ levels were divided by 3 and 2 , respectively. For groups $4,5,6$ and $7\left(13.4\right.$ to $36.6 \mathrm{mM} \mathrm{Gl}$ ), the plasma $\mathrm{T}_{4}$ levels did not differ significantly, amounting to about $30 \%$ of those in the controls. Plasma $T_{3}$ levels continued to drop (from 38 to $22 \%$ of that in control animals for groups 4 to 7 ) as the dietary glucosinolate content increased (fig. 6). 
Plasma concentrations of thyroxine $\left(\mathrm{T}_{4}, \mathrm{p} \mathrm{g} / \mathrm{dl}\right)$ and triiodothyronine $\left(\mathrm{T}_{3}, \mathrm{ng} / \mathrm{dl}\right)$ in rats of different groups at the end of the experiment.

\begin{tabular}{ccc}
\hline Group $\mathrm{n}^{\circ}$ & $\mathrm{T}_{3}$ & $\mathrm{~T}_{4}$ \\
\hline 1 & $48.2 \pm 6.6$ & $4.8 \pm 0.7$ \\
2 & $20.8 \pm 1.4^{* *}$ & $1.7 \pm 0.1^{* *}$ \\
3 & $25.4 \pm 5.2^{*}$ & $1.6 \pm 0.1^{* *}$ \\
4 & $18.4 \pm 2.3^{* *}$ & $1.5 \pm 0.1^{* *}$ \\
5 & $13.8 \pm 0.8^{* *}$ & $1.4 \pm 0.1^{* *}$ \\
6 & $10.6 \pm 0.6^{* *}$ & $1.3 \pm 0.1^{* *}$ \\
7 & $10.7 \pm 0.7^{* *}$ & $1.4 \pm 0.1^{* *}$ \\
\hline
\end{tabular}

Statistical significance : ${ }^{*} \mathrm{P}<0.05 ;{ }^{*} \mathrm{P}<0.01$; comparaison with controls ( $U$ test of Mann and Whitney).

\section{Discussion and conclusion.}

The results of this study show that after adaptation, rat feed consumption and growth rate were reduced almost linearly, with the increase in dietary glucosinolate concentration from 0 to $25 \mathrm{mM} / \mathrm{kg}$, and then more slowly between 25 and $36.6 \mathrm{mM} / \mathrm{kg}$. Trial conditions were such that it was not possible to determine the respective effects of ITC and VTO since the proportions of these compounds were similar in the two rapeseed meals.

One of the most interesting results of this study is the stabilization of intake and growth rate from day 8 and their reduction from day 11 . This reduction accelerated, and during the last 7 days it was proportional to the dietary glucosinolate concentrations; growth rate was close to zero. This variation in time cannot be explained by the poor palatability of the rapeseed meal due to the presence of sinapine since the rats were adapted progressively to the diets and their performance improved between days 3 and 8 . It was shown that rats adapt to the presence of sinapine in the diet within one week (Vermorel, Hocquemiller and Evrard, 1987). Moreover, Lee, Pittam and Hill (1984) showed that a reduction in feed intake by growing pigs receiving rapeseed was due to the presence of glucosinolates rather than to sinapine or tannins. Finally, the addition of progoitrin and myrosinase to a control diet caused a marked drop in intake and growth rate over 15 days (Vermorel, Heaney and Fenwick, 1986).

It is likely that glucosinolate products, and especially VTO, inhibit thyroid hormone synthesis (Moreale and Escobar, 1967) and that the animal progressively utilizes its reserves. The effect probably increases with increasing dietary glucosinolate concentrations (Vermorel, Fayet and Baudet, 1978), at very low levels, plasma $\mathrm{T}_{4}$ content is not reduced in rats ; similarly, in pigs the size and structure of the thyroid gland are not altered (Thomke, 1984). In contrast, at relatively low glucosinolate concentrations $(4.4 \mathrm{mM} / \mathrm{kg})$, plasma $T_{4}$ and $T_{3}$ contents are reduced by 65 and $50 \%$, respectively, showing that in rats, as in pigs, the functioning of the thyroid is very sensitive to the presence of glucosinolates. In pigs receiving only $1.7 \mathrm{mM}$ glucosinolates per $\mathrm{kg}$ of feed, the thyroid is incapable of responding to an infusion of thyrotropin-releasing hormone (TRH) by increased $T_{4}$ secretion, 
as opposed to the reaction of control animals (Christison and Laarveld, 1981). However, the performance of growing pigs receiving 4 or $5 \mathrm{mM}$ of glucosinolates $/ \mathrm{kg}$ of feed is not modified (Narendran et al., 1981; Thomke, 1984), and that of rats in the present study dropped by only $6 \%$, even during the last 7 days, although it may be questioned whether the reduction would have increased over a long period of time.

Glucosinolate intake generally causes an increase in liver size, fatty infiltrations, many changes in enzyme activity, necrosis and regeneration in rats (Oliver, McDonald and Opuzynska, 1971). There seem to be fewer anomalies in the liver structure of pigs (Thomke, 1984). However, contrary to all the other results obtained on rats and pigs fed diets rich in glucosinolates, those in the present study show that a high intake did not modify relative liver weight. The phenomenon could result in part from the utilization of dehulled rapeseed meal from which we had removed a large part of the tannins responsible for liver enlargment, according to Just, Hansen and Jensen (1982). Nevertheless, intake of purified progoitrin and myrosinase cause liver weight to double (Vermorel, Heaney and Fenwick, 1987). The present observations could also be explained by the marked reduction in intake at the end of the trial in rats receiving high concentrations of glucosinolate. Lastly, the very mild heat treatment applied to the rapeseed may have prevented the formation of compounds toxic to the liver.

In conc/usion, the effects of glucosinolates on rat performance are approximately proportional to the concentration of dietary glucosinolates ; these effects begin to appear about 10 days after the beginning of rapeseed intake and increase with time, reducing growth rate to zero. In contrast, the effects on thyroid function are maximal at low concentrations, suggesting that the reduction in plasma $T_{4}$ and $T_{3}$ levels is not the sole cause of the reduction in feed intake and growth rate. According to these results on rats, it may be assumed that the amount of rapeseed meal that can be used in the diet of growing pigs depends on the concentration and nature of the glucosinolates present and the technological treatments they undergo.

Reçu en juillet 1986,

Accepté en novembre 1986.

Acknowledgements. - This study was a part of the CETIOM/INRA programme on Oil seed crop research and received financial aid from the CETIOM.

Résumé. Valorisation du tourteau de colza. 3. Influence de la teneur en glucosinolates sur la consommation d'aliment, le gain de poids, le poids du foie et les teneurs en hormones thyroïdiennes du plasma chez le rat en croissance.

Sept groupes de 10 rats mâles en croissance ont reçu un régime témoin ou des régimes à base de tourteau de colza dont la teneur en glucosinolates variait de 4,4 à $36,6 \mathrm{mM} / \mathrm{kg} \mathrm{MS}$. Après une période d'adaptation de 5 jours, les rats ont été alimentés ad libitum pendant 17 jours.

La consommation d'aliment des rats recevant du colza a atteint son maximum au bout de 11 jours et était inférieure de 4 à $45 \%$ à celle du lot témoin. Les différences étaient encore plus importantes au cours des 7 derniers jours de l'expérience. Le gain de poids vif a été maximum au bout de 8 jours et a commencé à diminuer jusqu'à $1 \mathrm{~g}$ par jour au cours 
des derniers jours. Il existe des relations curvilinéaires entre la consommation d'aliment ou le gain de poids et la teneur en glucosinolates des régimes.

Le poids du foie ( $\mathrm{g} / 100 \mathrm{~g}$ de poids vif) n'a pas été modifié significativement par des ingestions de glucosinolates variant de 0,08 à $0,31 \mathrm{mM} /$ jour. Cependant, les concentrations en $\mathrm{T}_{3}$ et $\mathrm{T}_{4}$ dans le plasma étaient inférieures à celle du lot témoin : de $50 \%$ et 70 à $80 \%$ pour les teneurs les plus faibles ou les plus fortes en glucosinolates des régimes.

\section{References}

BELL J. M., 1984. Nutrients and toxicants in rapeseed meal : a review. J. anim. Sci., 58, 996-1010.

CHONE E., 1983. Qualité des produits de transformation du colza double-zéro. C.-R. Acad. Agric. France, 69, 17-29.

CHRISTISON G. 1., LAARVELD B., 1981. Thyroïd hormone response to thyrotropin releasing hormone by pigs fed canola, rapeseed or soybean meals. Can. J. anim. Sci., 61, 1023-1029.

JUST A., HANSEN V., JENSEN A., 1982. Quoted by RUNDGREN M., 1983.

LEE P. A., PITTMAN S., HILL R., 1984. The voluntary food intake by growing pigs of diets containing " treated " rapeseed meals or extracts of rapeseed meal. Br. J. Nutr., 52, 159-164.

MCKINNON P. J., BOWLAND J. P., 1977. Comparison of low glucosinolate-low erucic acid rapeseed meal (cv. Tower), commercial rapeseed meal and soybean meal as sources of protein for starting, growing and finishing pigs and young rats. Can. J. anim. Sci., 57, 663-678.

MOREALE DE ESCOBAR G., ESCOBAR DEL REY F., 1967. Extrathyroïd effects of some antithyroïd drugs and their metabolic consequences. Recent Progr. Hormone Res., 23, 87-131.

MORICE J., 1974. Sélection d'une variété de colza sans acide érucique et sans glucosinolates. 4th int. Rapskongress, Giessen, 31-47.

MORICE J., 1983. Un nouveau colza : le colza double-zéro. C.-R. Acad. Agric. France, 69, 7-16.

NARENDRAN R., BOWMAN G. H., LEESON S., PFEIFFER W., 1981. Effect of different levels of Tower rapeseed meal in corn-soybean meal based diets on growing-finishing pig performance. Can. J. anim. Sci., 61, 213-216.

OLIVER S. L., MCDONALD B. E., OPUZYNSKA T., 1971. Weight gain, protein utilization and liver histochemistry of rats fed low-and high-thioglucoside-content rapeseed meals. Can. J. Physiol. Pharmacol., 49, 448-456.

RUNDGREN M., 1983. Low-glucosinolate rapeseed products for pigs. Anim. Feed. Sci. Technol., 9. 239-262.

SNEDECOR G. W., COCHRAN W. G., 1968. Statistical methods, 6th ed. The lowa Univ. Press, Ames, lowa, USA.

THIES W., 1978. Quantitative analysis of glucosinolates after their enzymatic desulfatation on ion exchange columns, 136-139. 5th int. Rapeseed Conf. Malmo, 12-16 june.

THOMKE S., 1984. Further experiments with RSM of a Swedish low-glucosinolate type to growing-finishing pigs. Swedish J. agric. Res., 14, 151-157.

THOMKE S., ELWINGER K., RUNDGREN M. and AHLSTROM B., 1983. Rapeseed meal of Swedish low-glucosinolate type fed to broiler chickens, laying hens and growing-finishing pigs. Acta agric. scand., 33, 75-95.

VERMOREL M., 1972. Besoins énergétiques et azotés du rat en croissance. Expériment. anim., 5, 249-266.

VERMOREL M., FAYET J. C., BAUDET J. J., 1978. Valorisation du tourteau de colza. 1. Influence de l'élimination des glucosinolates, du dépelliculage et de l'extraction des alpha-galactosides sur sa valeur nutritive. Etude sur le rat en croissance. Ann. Biol. anim. Bioch. Biophys., 18, 1393-1412.

VERMOREL M., HEANEY R. K., FENWICK G. R., 1987. Antinutrional effects of progoitrin and myrosinase (in preparation).

VERMOREL M., HOCQUEMILLER R., EVRARD J., 1987. Valorization of rapeseed meal. 4. Effects of sinapin and other phenolic compounds on food intake and weight gain of growing rats and diet protein utilization. Reprod. Nutr. Dévelop. (in preparation).

YOUNGS C. G., WETTER L. R., 1967. Microdetermination of the major individual isothiocyanates and oxazolidinethione in rapeseed. J. amer. Oil Chem. Soc., 44, 551-554. 